\title{
Planning hydrological restoration of peatlands in Indonesia to mitigate carbon dioxide emissions
}

\author{
Julia Jaenicke • Henk Wösten • Arif Budiman • \\ Florian Siegert
}

Received: 18 September 2009 / Accepted: 5 January 2010 /

Published online: 3 February 2010

(C) The Author(s) 2010. This article is published with open access at Springerlink.com

\begin{abstract}
Extensive degradation of Indonesian peatlands by deforestation, drainage and recurrent fires causes release of huge amounts of peat soil carbon to the atmosphere. Construction of drainage canals is associated with conversion to other land uses, especially plantations of oil palm and pulpwood trees, and with widespread illegal logging to facilitate timber transport. A lowering of the groundwater level leads to an increase in oxidation and subsidence of peat. Therefore, the groundwater level is the main control on carbon dioxide emissions from peatlands. Restoring the peatland hydrology is the only way to prevent peat oxidation and mitigate $\mathrm{CO}_{2}$ emissions. In this study we present a strategy for improved planning of rewetting measures by dam constructions. The study area is a vast peatland with limited accessibility in Central Kalimantan, Indonesia. Field inventory and remote sensing data are used to generate a detailed 3D model of the peat dome and a hydrological model predicts the rise in groundwater levels once dams have been constructed. Successful rewetting of a $590 \mathrm{~km}^{2}$ large area of drained peat swamp forest could result in mitigated emissions of 1.4-1.6 $\mathrm{Mt} \mathrm{CO}_{2}$ yearly. This equates to $6 \%$ of the carbon dioxide emissions by civil aviation in the European Union in 2006 and can be achieved with relatively small efforts and at low costs. The proposed methodology allows a detailed planning of hydrological restoration of peatlands with interesting impacts on carbon trading for the voluntary carbon market.
\end{abstract}

Keywords Dam construction - Drainage canal - Groundwater level rise · Hydrological modelling . Illegal logging

J. Jaenicke $(\square) \cdot$ F. Siegert

GeoBio Center, Ludwig-Maximilians-University Munich \& Remote Sensing Solutions GmbH,

Wörthstrasse 48, 81667 München, Germany

e-mail: jaenicke@rssgmbh.de

H. Wösten

Alterra, Wageningen University and Research Centre, P.O. Box 47, 6700 AA Wageningen,

The Netherlands

A. Budiman

WWF-Indonesia, Kantor Taman A9, Unit A-1, Kawasan Mega Kuningan, Jakarta 12950, Indonesia 


\section{Introduction}

Of the tropical peatlands worldwide $70 \%$ are located in Southeast Asia, 22 million ha of these in coastal and sub-coastal regions on the islands of Sumatra, Borneo and West Papua in Indonesia (Page and Banks 2007). Tropical peat is an accumulation of partially decayed organic matter which has been formed over thousands of years in waterlogged environments that lack oxygen. In Indonesia peat deposits with up to $20 \mathrm{~m}$ in thickness store huge amounts of carbon (Whitten et al. 1987; Sorensen 1993; Jaenicke et al. 2008). Under undisturbed conditions, tropical peatlands are covered with peat swamp forests which comprise ecosystems with many endemic species and high biodiversity. Since the 1980s the Indonesian peatlands have been extensively logged, drained and converted to plantation estates as a result of economic development (Curran et al. 2004; Rieley and Page 2005; Hansen et al. 2009). In Southeast Asia 12 million ha of peatlands are currently deforested and drained, including over 1.5 million ha of tropical peat swamp forests in the Indonesian province of Central Kalimantan (Hooijer et al. 2006). Canals and ditches are not only built to control and lower the groundwater level for plantation operations and small-scale agriculture but also to facilitate access to peat swamp forests and to extract timber logs. The extent of these diverse canals and thus the impact on drainage depth varies. For example, the drainage depth of oil palm plantations in Sarawak, Malaysia, is $-60 \mathrm{~cm}$ (Melling et al. 2005) whereas it is about $-30 \mathrm{~cm}$ in farm fields in Central Kalimantan, Indonesia (Jauhiainen et al. 2004).

Once peat is drained, it oxidises due to microbial activity and releases stored carbon to the atmosphere as carbon dioxide. This ongoing rapid peat decomposition leads to the irreversible process of peatland subsidence. In developed peat, drainage depth is related to peat organic matter oxidation rates and peat subsidence (Wösten et al. 1997; Furukawa et al. 2005). On average $60 \%$ of peat subsidence is caused by oxidation and $40 \%$ by irreversible drying or shrinkage of the peat (Wösten et al. 1997). Lowering the groundwater level which naturally is close to the peat surface throughout the year while fluctuating with the intensity and frequency of rainfall, results in an increase in $\mathrm{CO}_{2}$ emissions. In a recent review it is estimated that an increase of drainage depth by $10 \mathrm{~cm}$ results in the emission of about $9 \mathrm{t} \mathrm{CO}_{2} \mathrm{ha}^{-1} \mathrm{a}^{-1}$ (Couwenberg et al. 2009).

Another severe consequence of drainage is the occurrence of peat fires. Under natural circumstances peat consists of $90 \%$ water and $10 \%$ plant matter and hardly ever burns. However, if the groundwater level falls below a critical threshold of $-40 \mathrm{~cm}$, the dry peat surface becomes susceptible to fire (Takahashi et al. 2003; Usup et al. 2004; Wösten et al. 2008). Fires are most severe during El Niño events, as in 1997/98 when about 2.4-6.8 million ha of peatlands burnt in Indonesia releasing huge amounts of the greenhouse gas $\mathrm{CO}_{2}(\mathrm{Page}$ et al. 2002; Van der Werf et al. 2008). With a groundwater level at about $-100 \mathrm{~cm}$ the burn depth was estimated to be $51 \mathrm{~cm}$ on average releasing up to $9.4 \mathrm{Gt}$ of carbon dioxide in Indonesia (Page et al. 2002). The failed Mega Rice Project, a resettlement project initiated in 1995 in Central Kalimantan, contributed largely to this ecological devastation. Drainage canals, up to $30 \mathrm{~m}$ wide and $10 \mathrm{~m}$ deep, with a combined length of 4,500 km disrupted the peatland ecosystem over an area of more than 1 million ha. There exists a positive feedback of recurrent fires which leads to progressive forest degradation and continuous release of $\mathrm{CO}_{2}$ with regional and global consequences for the environment and climate (Siegert et al. 2001; Cochrane 2003; Langner et al. 2007).

Complete rewetting is the only way to prevent fires and peat oxidation by microbial decomposition. Due to its high permeability peat acts as a sponge, i.e. it shrinks when dried and swells when rewetted, unless water contents fall below a threshold value at which 
irreversible drying occurs (Wösten et al. 2008). Therefore, one of the most important peatland restoration measures is blocking of drainage canals by dams and thus raising the groundwater level of the surrounding peatland. Damming activities performed in the former Mega Rice Project area, in Sebangau National Park and in Merang peatland of South Sumatra have shown that the water retention upstream of dams could be increased thereby decreasing peat desiccation during the dry season (Suryadiputra et al. 2005; CKPP 2008; Jauhiainen et al. 2008). Few rehabilitation attempts have been undertaken in the past (Page et al. 2008), however within the context of ongoing discussions concerning climate change tropical peatlands have now been recognised as major sources of greenhouse gas emissions (Rieley and Page 2005; Hooijer et al. 2006; Uryu et al. 2008). The carbon content of the peat soils in Indonesia is about 18 times higher than that of pristine peat swamp forest (Jaenicke et al. 2008). Therefore, peatland rehabilitation projects are of high interest for carbon trading on the voluntary carbon market. While peat oxidation causes continuous release of carbon dioxide, peat fires are the source of huge amounts of $\mathrm{CO}_{2}$ emissions in short time. These emissions can be mitigated if peatland rewetting measures are implemented.

The objective of this study was the development of an efficient and cost-effective methodology to plan hydrological restoration of disturbed tropical peatlands. The study was conducted in the Sebangau catchment in Central Kalimantan under supervision of the World Wildlife Fund (WWF) aiming at mitigation of carbon dioxide emissions. The surface of tropical peat shows little slope; with gradients of only $0.2-1 \mathrm{~m}$ per kilometre in the centre they appear virtually flat (Page et al. 1999; Rieley and Page 2005). In addition, the Sebangau peat dome is covered with dense vegetation which makes an in situ assessment of the entire hydrology impossible. The proposed restoration programme comprises several steps: 1) planning: selection of locations best suited for effective restoration measures and dam construction, 2) hydrological modelling: predicting the effect of dams, 3) implementation: dam construction, 4) monitoring: monitoring the performance of dams in time. The methodology presented here for steps 1) and 2) builds on a combined approach of field inventory, remote sensing, geospatial analysis and 3D peat dome topography assessment as well as sophisticated hydrological modelling. Steps 3) and 4) are briefly discussed in Section 4 and will remain as a future research topic.

\section{Study area, materials and methods}

\subsection{Study area}

The hydrological restoration project will be carried out in a $1,480 \mathrm{~km}^{2}$ area of the Sebangau catchment which is located in the Indonesian province of Central Kalimantan on the island of Borneo (Fig. 1). The catchment is part of a 7,347 $\mathrm{km}^{2}$ large peat dome which contains the largest remaining continuous area of dense peat swamp forest in Borneo and stores about 2.3 Gt of peat soil carbon (Jaenicke et al. 2008). The extent of the study area is defined by natural, hydrological borders, i.e. the Sebangau River to the east, tributary streams to the southwest and north and the highest elevation of the peat dome to the northwest. As most Indonesian peatlands the Sebangau peat dome is ombrogenous, i.e. rainfall is the only source of water and nutrients. Organic matter accumulation started around 26,000 years ago (Page et al. 2004). The climate of Central Kalimantan is determined by a dry season which usually begins in May and lasts until October and a wet season from November until April. Annual rainfall varies between 2,000 and 4,000 mm and is influenced by periodic El Niño events which cause a prolonged dry season. During the 


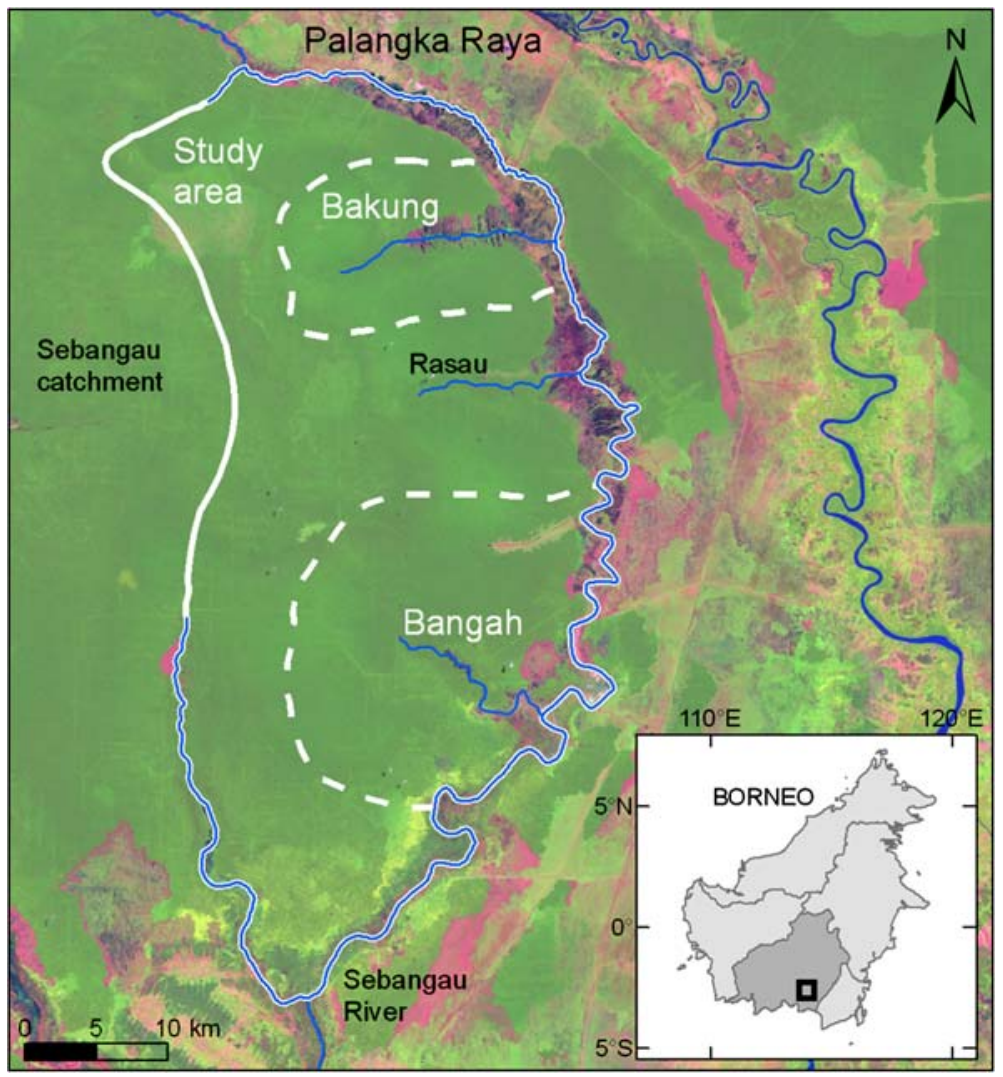

Fig. 1 Landsat ETM+ satellite image from August 2007 showing the study area located in Central Kalimantan on the island of Borneo, Indonesia. Dark green: peat swamp forest, red: fire scars in the year 2006

dry season the groundwater level in the peat drops as precipitation decreases. The Sebangau ecosystem is renowned for its high conservation value and important natural resource functions. Consequently, the Sebangau catchment was designated as National Park in 2004, also to protect the largest population in the world of the endangered Bornean orang-utan. Nevertheless, the Sebangau peat dome is suffering from serious drainage in recent years due to the construction of hundreds of canals by illegal loggers. Until 1997 timber concessions constructed thousands of kilometres of simple railway tracks to transport felled timber to the Sebangau River (Boehm and Siegert 2004). The concession companies removed their infrastructure equipment but illegal loggers excavated canals along the former railway tracks to enable timber transport (Fig. 2). Difficult access restricts the knowledge of the total number of canals in Sebangau peat dome to estimations by local fisherman and environmental organisations. In this study, field surveys were conducted to map all canals within two specific areas located in the eastern part of the peatland. Burn scars occurring on Landsat satellite imagery since 1997 as well as fire hotspots yearly detected by the MODIS satellite sensors (FIRMS 2009) demonstrate the negative impacts of canal drainage on the Sebangau peatland.

The eastern part of the Sebangau catchment was selected for hydrological restoration due to its vicinity to the city of Palangka Raya and its relative easy access via the Sebangau 


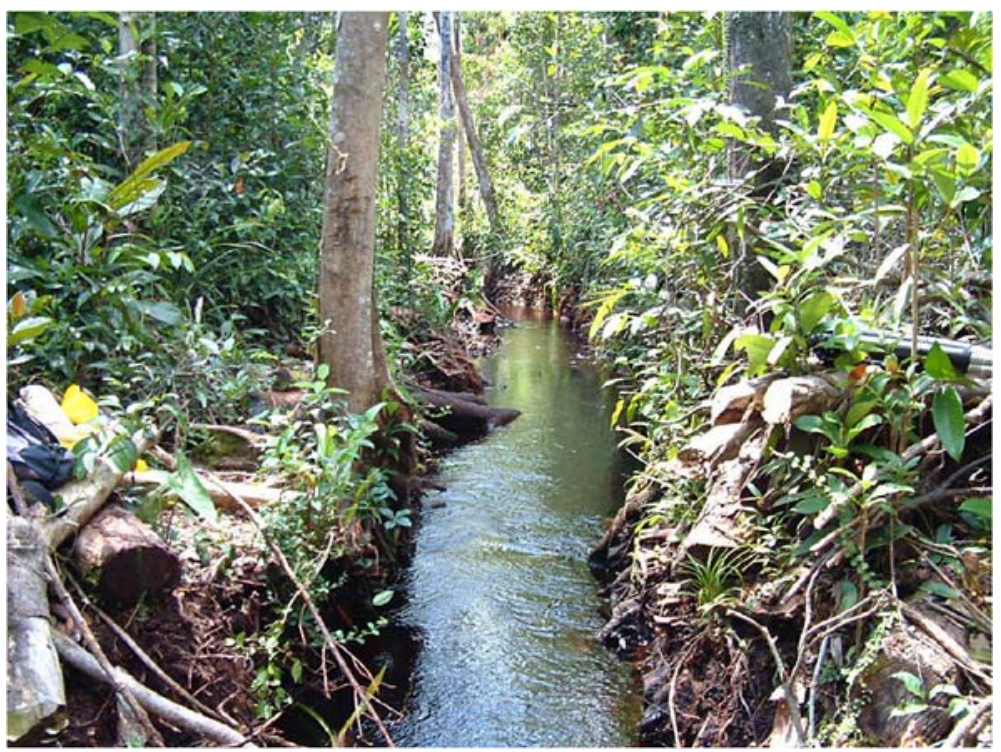

Fig. 2 Typical drainage canal in the Sebangau catchment used to transport timber

River and tributary streams. Two water sub-catchments, named after their main outlet rivers Bakung and Bangah, were identified for the project (Fig. 1). Outlet rivers give loggers access to the forest and thus most drainage canals start there. On the basis of a Digital Terrain Model (DTM) the two catchments were delineated comprising a total area of $590 \mathrm{~km}^{2}$. It is assumed that if all canals actually draining the peat within a specific catchment are blocked, it will be possible to permanently raise groundwater levels to the original situation in which groundwater levels are normally at or close to land surface.

\subsection{Remote sensing}

Difficult access of tropical peat swamp forests and limited project funds, require the use of remote sensing data and modelling techniques in combination with field surveys of canal attributes. Optical satellite imagery from Landsat ETM+, SPOT HRVIR and ALOS AVNIR sensors, radar satellite data from the Shuttle Radar Topography Mission (SRTM) and high resolution airborne laser scanning data (LIDAR) were used to: 1) generate a Digital Terrain Model (DTM) of the peat surface and determine peat thickness, and 2) localise drainage canals for hydrological modelling of groundwater levels. Hydrological modelling allows identification of areas with good restoration potential and helps to optimise the number and location of dams required for rewetting a specific area. Canal location, length, width, depth and slope as well as peat bulk density, hydraulic conductivity and the stratification by peat thickness are required parameters for the modelling.

LIDAR (LIght Detection And Ranging) measurements were acquired in August 2007 for the northern part of the study area along a $34 \mathrm{~km}$ long and $0.4 \mathrm{~km}$ wide flight stripe running from west to east. LIDAR systems are active, airborne remote sensing systems which radiate pulses of laser light to the terrain and measure the time delay between transmission of the pulse and measurement of the reflected signal by the sensor. The three dimensional clouds of points were differentiated into ground points and non-ground points reflected from vegetation. To extract ground points from vegetation points the terrain-adaptive bare 
earth filtering algorithm from Cloud Peak software was applied (Ballhorn et al. 2009). LIDAR measurements allow assessing the terrain height beneath forests with unrivalled accuracy. The ground surface generated by airborne Laser data has a spatial resolution of $1 \mathrm{~m}$. LIDAR data were used to assess the peat dome topography across the Sebangau catchment and to validate the DTM generated for the study area.

The elevation of the DTM was calculated from SRTM imagery acquired in February 2000. Kriging interpolation in ArcGIS was used to generate a dome shaped peat surface model as indicated by the LIDAR and SRTM data. For this surface grid points at 500$1,000 \mathrm{~m}$ intervals extracted from the SRTM data, were interpolated. SRTM data represent in deforested peat areas a Digital Terrain Model (DTM), i.e. bare-earth model. However, in forested areas they display a so called Digital Surface Model (DSM) because the SRTM Cband radar sensor does not penetrate the dense peat swamp forest cover. The tree canopy height was estimated by means of deforested patches, like burn scars, rivers and canals. Different peat swamp forest types were identified by analysing their texture variations in the radar imagery in combination with spectral information from a Landsat ETM+ image also acquired in February 2000. The terrain model, together with peat drilling data, formed the basis for modelling peat thickness. Peat thickness drillings using manually operated peat corers are laborious and expensive. The limited terrain accessibility restricts these drillings usually to sites adjacent to drainage canals and along logging railway tracks. A total of 129 drilling measurements were available for the study area but not evenly distributed to directly apply spatial interpolation. Therefore, correlation was used to provide missing peat thickness information (Jaenicke et al. 2008). The correlation function makes use of a biconvex shape model typically for ombrogenous, tropical peatlands (Rieley and Page 2005; Jaenicke et al. 2008). A strong correlation coefficient of $r=0.87$ was obtained between peat surface and peat thickness.

\subsection{Hydrological modelling}

For hydrological modelling, the physically-based SIMGRO (SIMulation of GROundwater flow and surface water levels) model was used to simulate water flow in the saturated zone, unsaturated zone, river channels and over the peat surface (Querner et al. 2008; Querner and Povilaitis 2009). Using the DTM and the watercourses map, delineations of the project area were determined with the hydrology extension in the GIS package ArcView. Saturated groundwater flow was modelled using the finite element method for which the model area was subdivided into triangular segments. The top of the mineral layer was set as aquifer bottom. Hydraulic conductivity of the peat is an essential element of hydrological modelling. In turn, the hydraulic conductivity and also the moisture retention relationship of the peat is strongly influenced by the degree of humification of the peat. Based on hydraulic conductivity measurements using the pumping test method as reported by Ong and Yogeswaran (1992) and by Takahashi and Yonetani (1997) the peat profile in this study is schematised in a two layer system consisting of a fibric to hemic peat top layer $(0-1 \mathrm{~m})$ with an average hydraulic transmissivity (cumulative thickness multiplied by conductivity) of $30 \mathrm{~m}^{2} \mathrm{~d}^{-1}$ and a deeper, sapric peat layer with an average hydraulic transmissivity of $2.2 \mathrm{~m}^{2} \mathrm{~d}^{-1}$. While using these average values it should be realised that the relatively few measurements available for tropical peatlands show a considerable range. In addition, a peat water storage coefficient is required as a model input parameter. This coefficient was not measured directly but obtained in the model calibration process and set to 0.5 (Wösten et al. 2006). Groundwater levels calculated using both the original and calibrated model for the test site directly south of Palangka Raya (Fig. 1) are shown in Fig. 3a. The correlation 

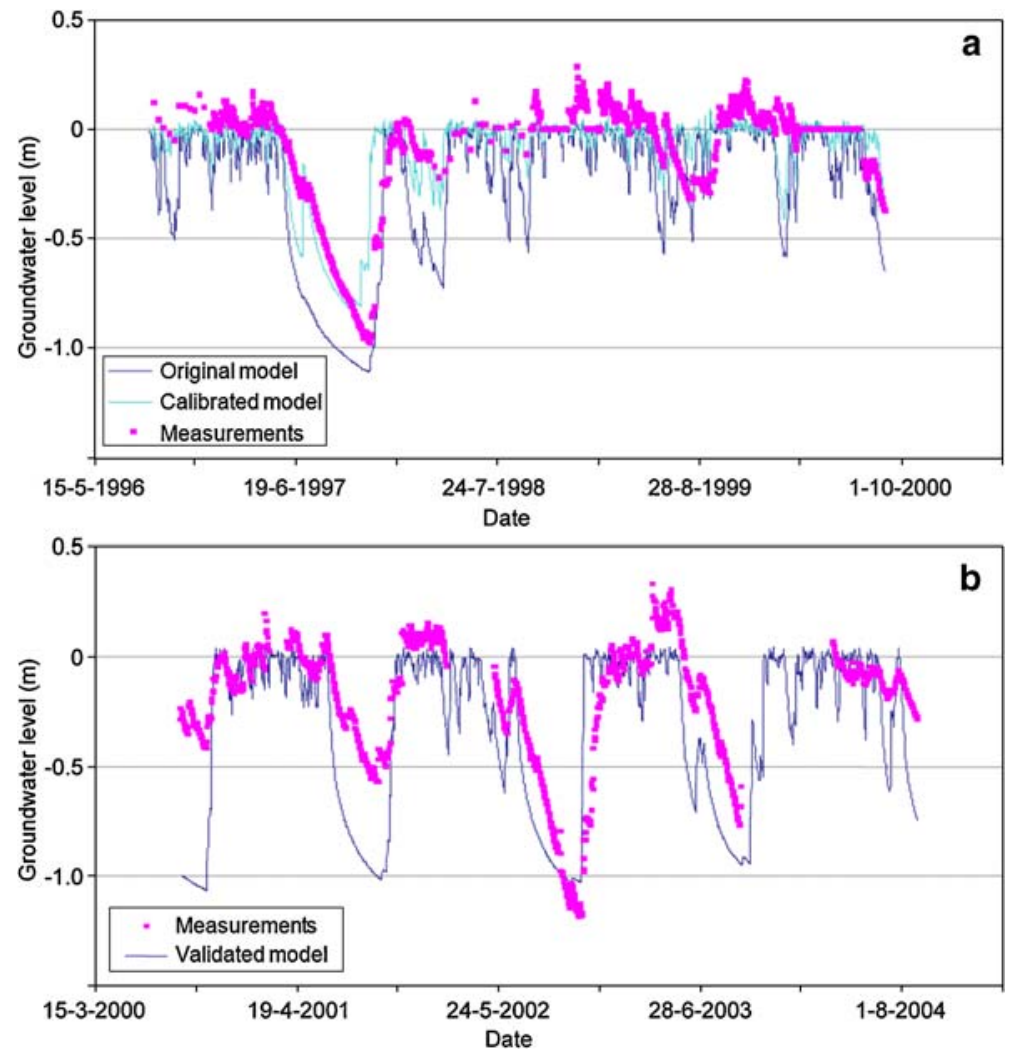

Fig. 3 Measured and calculated groundwater levels relative to land surface at the test site $($ Lat $=2.323 \mathrm{~S}$, Lon $=$ 113.903 E) versus time. a Model calibration, b Model validation

coefficient $\left(R^{2}\right)$, the root mean square error (RMSE) and the mean square error (MSE) for the calibrated model are $0.74,5.22$ and 7.79 respectively. After calibration the model was validated and the results are shown in Fig. 3b. The calibrated and validated model represents groundwater levels measured in a dip well at the test site with acceptable accuracy (within $0.10 \mathrm{~m}$ ).

\section{Results}

\subsection{Peat dome 3D topography}

The 3D topography of the peat layer is an essential input for hydrological modelling of groundwater levels. The DTM of the peat dome surface was used for slope calculations to identify water sub-catchments and to determine the number and location of dams for hydrological restoration. LIDAR data analysis showed that the surface of the Sebangau peat dome towards the centre is elevated by a maximum of $13 \mathrm{~m}$ above its margins with an average gradient of $0.7 \mathrm{~m}$ per kilometre which appears flat when in the field (Fig. 4). The SRTM derived peat dome surface correlates very well with the LIDAR measurements; the average discrepancy is only $0.35 \mathrm{~m}$ (Fig. 4). The LIDAR as well as SRTM DSM reveal 


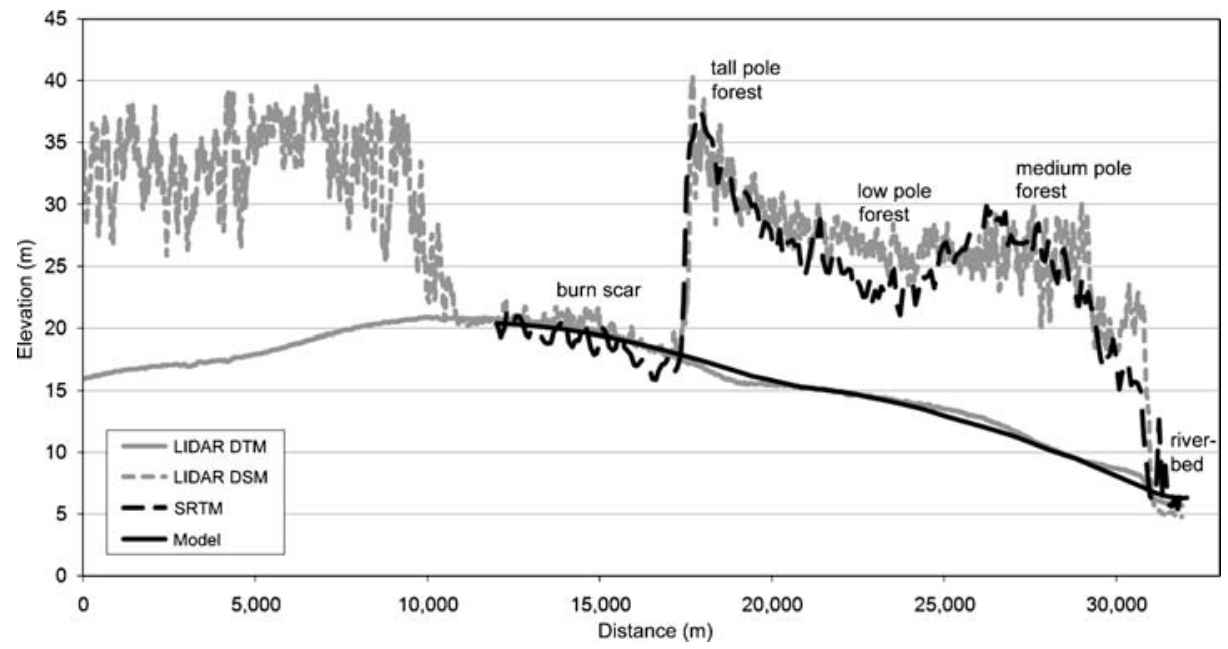

Fig. 4 The LIDAR DTM and the peat surface derived from SRTM data (Model) agree very well. The SRTM DSM data reveal relative canopy heights of various peat swamp forest types

different peat swamp forest types (low, medium, tall pole), which in accordance with field investigations have different maximum canopy heights depending on local substrate conditions (Page et al. 1999). Biomass data, i.e. breast height diameter, tree height and tree species, were collected in October 2007 and 2008 along the transect shown in Fig. 4 and these data confirm the results. Even across large distances with little relief it is possible to derive the DTM from the SRTM DSM using spatial interpolation between deforested patches. The result was a detailed DTM of the Sebangau peat dome and its sub-catchments with $30 \mathrm{~m}$ spatial resolution. Figure 5 shows the fine topography along cross sections in the middle of Bakung and Bangah catchments. The slope of the southern part of Bakung catchment appears relatively steep but the gradient is only $1 \mathrm{~m}$ per kilometre at maximum. Besides detailed peat dome topography, hydrological modelling requires peat thickness and bedrock data. The result of the thickness modelling reveals an average peat thickness of $5.4 \pm 0.95 \mathrm{~m}$ within the study area and a maximum depth of approximately $10.7 \mathrm{~m}$ in the centre of the Sebangau peat dome. The margin of error results from comparison of the peat thickness model with in situ measurements. The large deviations result probably from bedrock unconformity, which is not taken into account in the model. About half of the in

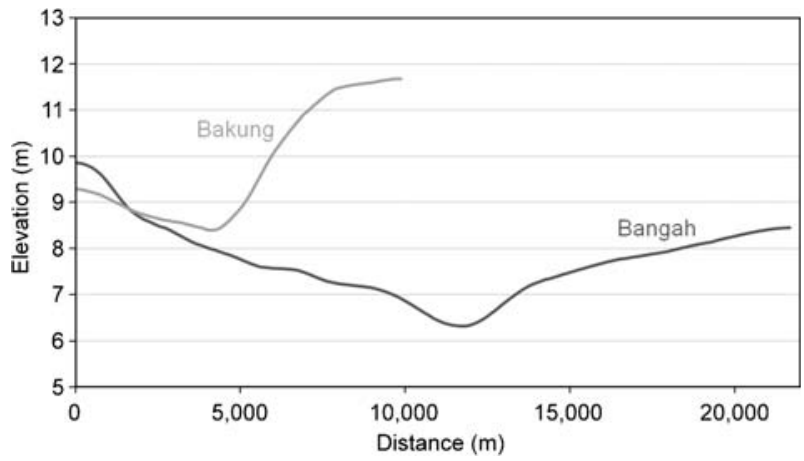

Fig. 5 DTM cross sections in the middle of the Bakung and Bangah catchment (from north to south) 
situ thickness values are larger than the model result, while the other half are smaller. This suggests that discontinuities in the mineral ground topography are balanced by spatial Kriging interpolation and thus the modelled volume results are close to reality (Jaenicke et al. 2008).

\subsection{Canal delineation}

During field surveys in the Bakung and Bangah catchments the origin of 65 drainage canals was recorded. Eventually all these canals need to be blocked to rewet the surrounding peatland. The field team also recorded direction, length, width and depth of all canals as well as water depth, water flow, mud sedimentation or weed growth. With an average depth of $0.7 \mathrm{~m}$ and an average width of $2.4 \mathrm{~m}$ the canals are relatively small in terms of their cross-sectional dimensions, but they are closely spaced with an average distance of about $200 \mathrm{~m}$ in the Bakung and of about $800 \mathrm{~m}$ in Bangah catchment and they extent for distances up to $13 \mathrm{~km}$. All information was stored in a geodatabase and a ranking was assigned indicating the priority of a canal to be closed. Long, wide and deep canals with a high water level and flow were assigned a high priority, whereas canals filled with mud and weeds were categorised as low priority. Twenty-two canals showed a high or medium need for closure. Canal lengths were estimated by consulting local people since access to the canals is very laborious and because GPS recordings are inaccurate due to dense forest cover hampering the GPS receiver. Narrow canals were invisible even from high resolution satellite images (SPOT and ALOS AVNIR, both at $10 \mathrm{~m}$ spatial resolution) because the tree canopy covers the streams (Fig. 6). However, knowing the outlet of the canal, the direction and approximate length it was possible to delineate most canals.

Fig. 6 SPOT satellite image from May 2004 showing the course of canals and railway tracks in the Bangah catchment as bright green lines as well as sites of illegal logging (pink and bright green "dots"). The origin of drainage canals recorded during field work is superimposed as yellow dots

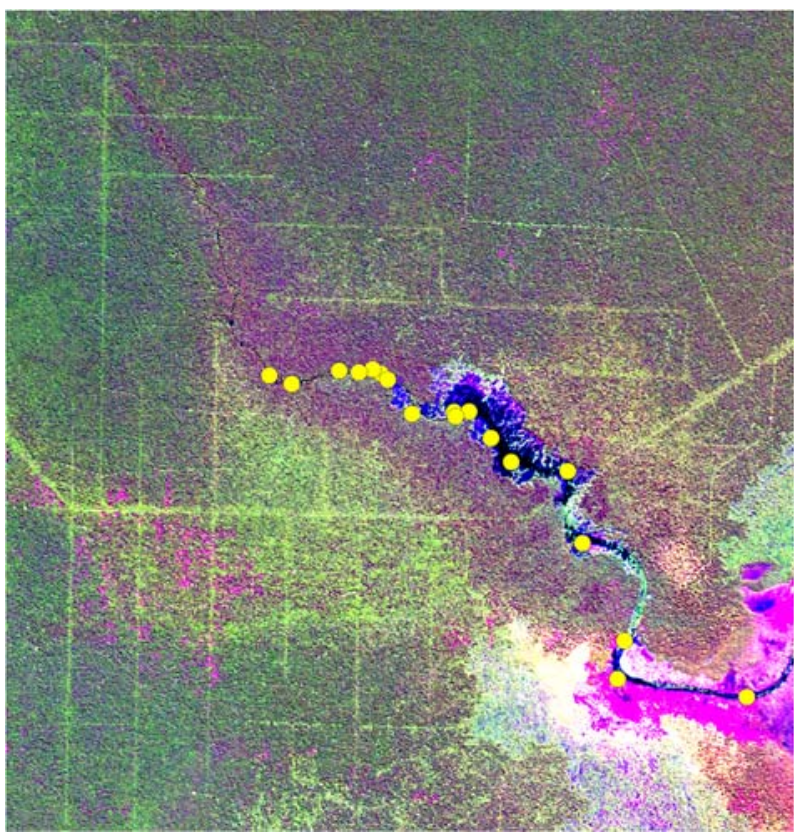




\subsection{Identification of locations for dam construction}

Dams act as flow barriers but they cannot store water for long periods as water will eventually seep through the surrounding peat. As dams restrict water flow rather than stop all water movement, they do not have to be watertight and thus construction can be relatively simple. To determine the optimal number and location of dams required for efficient drainage reduction, the surface slope was determined along each canal selected to be closed. Hydrological model simulations revealed that a cascade of closely spaced dams is most effective for water control (Wösten and Ritzema 2001). The steeper the slope, the more dams are needed to reduce drainage. Figure 7 shows the slope of a medium priority canal in the Bangah catchment (length $10 \mathrm{~km}$, width $3 \mathrm{~m}$, depth $1 \mathrm{~m}$ ). The absolute elevation difference of the canal from its origin at the top of the peat dome to its outlet into Bangah river is $3.1 \mathrm{~m}$. Because the slope of the canal is not constant over its total length it was subdivided into two sections: an upper, relatively flat section (Fig. 7, Slope1) and a lower, steep section (Fig. 7, Slope2). The distance between dams required to reduce drainage is determined by the hydraulic head difference, i.e. difference between upstream and downstream canal water level across a dam. Field experiments showed that for small canals the water level over each dam should be limited to about $25 \mathrm{~cm}$ to reduce seepage and to prevent erosion. Thus, the canal in Fig. 7 requires a series of 13 dams to overcome the $3.1 \mathrm{~m}$ elevation difference ${ }^{1}$. In the upper section of the canal a spacing of $975 \mathrm{~m}$ between dams is sufficient to keep water level differences low, while in the steeper section the spacing needs to be reduced to $320 \mathrm{~m}$. The Bakung catchment requires the construction of 141 dams to efficiently reduce drainage. For the Bangah catchment 84 dams are needed in addition to 30 dams previously constructed. Figure 8 shows the location of dams planned and already built, as well as the priority status of the canals superimposed on the DTM. The Bakung catchment is smaller than Bangah catchment but requires more dams because of the steeper topography and higher density of canals to be closed. Figure 9 shows an example of a relatively simple dam in the Bangah catchment mainly made of locally available material.

\subsection{Prediction of groundwater level rise}

The effect of dams on groundwater levels is predicted by hydrological modelling comparing the situation before and after dam construction. Figure 3 shows that in wet years calculated groundwater levels are at or close to land surface whereas in dry years they drop to about $1 \mathrm{~m}$ below land surface. On average the groundwater level at the undisturbed test site is $-16 \mathrm{~cm}$. This value provides an indication of the intended long-term average groundwater level after successful blocking of drainage canals in the Bakung catchment. The calibrated and validated hydrological model was applied to the whole of the Bakung and Bangah catchment for the 25 November 1997, an extremely dry period. Figure 10a shows that dams can raise groundwater levels up to 50-70 $\mathrm{cm}$ under these very dry weather and peat conditions. For larger areas the

\footnotetext{
$\overline{{ }^{1} \mathrm{H}(\text { slope } 1) / 0.25+\mathrm{H}(\text { slope } 2) / 0.25}+\ldots+\mathrm{H}\left(\right.$ slope $\left._{\mathrm{n}}\right) / 0.25=\mathrm{N}($ dams $)$

$\mathrm{D}\left(\right.$ slope $\left._{\mathrm{n}}\right) / \mathrm{N}($ dams $)=\mathrm{S}($ dams $)$

$\mathrm{H}$ maximum elevation difference of the canal within each "slope section"

$\mathrm{N}$ optimum number of dams (rounded up to be on the save side)

D distance of each "slope section"

$\mathrm{S}$ spacing between dams
} 
Fig. 7 Slope of the peat surface next to a canal in Bangah catchment as measured in the modelled DTM (0 marks the most upstream part of the canal). 13 dams are required to reduce large scale drainage

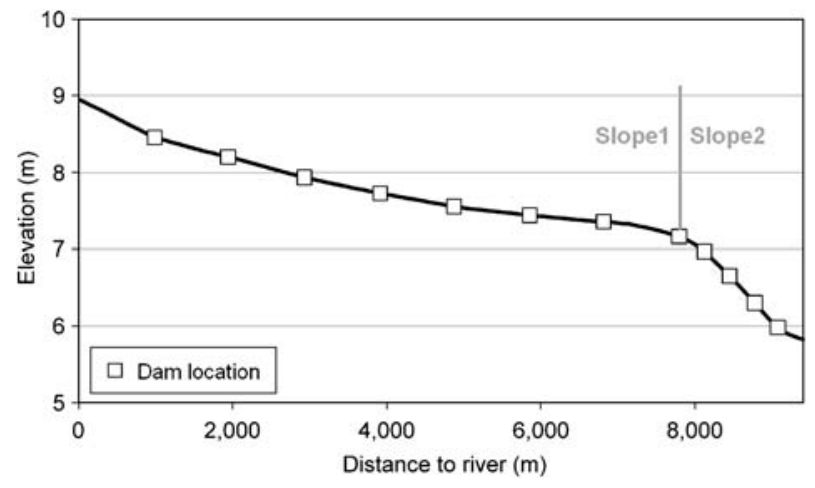

rise is approximately $10-30 \mathrm{~cm}$. Rise in groundwater levels is presented in classes rather than as absolute values to reflect the uncertainty in the calculated results. The areas affected by rewetting are strongly influenced by the slope of the peatland area surrounding the canal as this determines the catchment area draining to the canal. Figure 10b shows surface water levels in a $12 \mathrm{~km}$ long canal. Compared to the situation without dams, the result is a rise of the canal water level of up to $35 \mathrm{~cm}$ in the upstream part of the canal. The resulting rewetting of the peatland area surrounding this canal is up to $50 \mathrm{~cm}$. Hydrological modelling of the rise of groundwater levels on a daily base for the years 2006, 2007 and 2008 shows that on average this rise is $20 \mathrm{~cm}$ during the dry season. As a consequence, construction of dams considerably increases

Fig. 8 Location of dams to be constructed for an efficient reduction of drainage in the Bakung and Bangah catchments. Only canals ranked as medium and high priority should be closed. Data are superimposed on the peat surface DTM

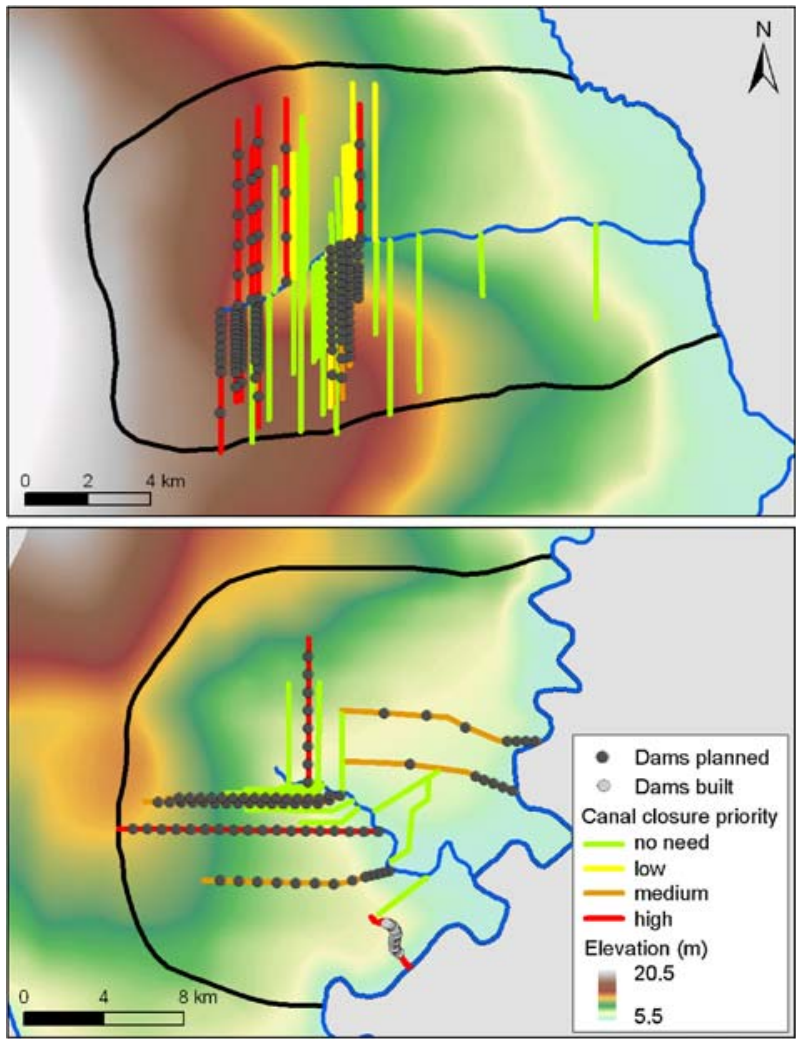




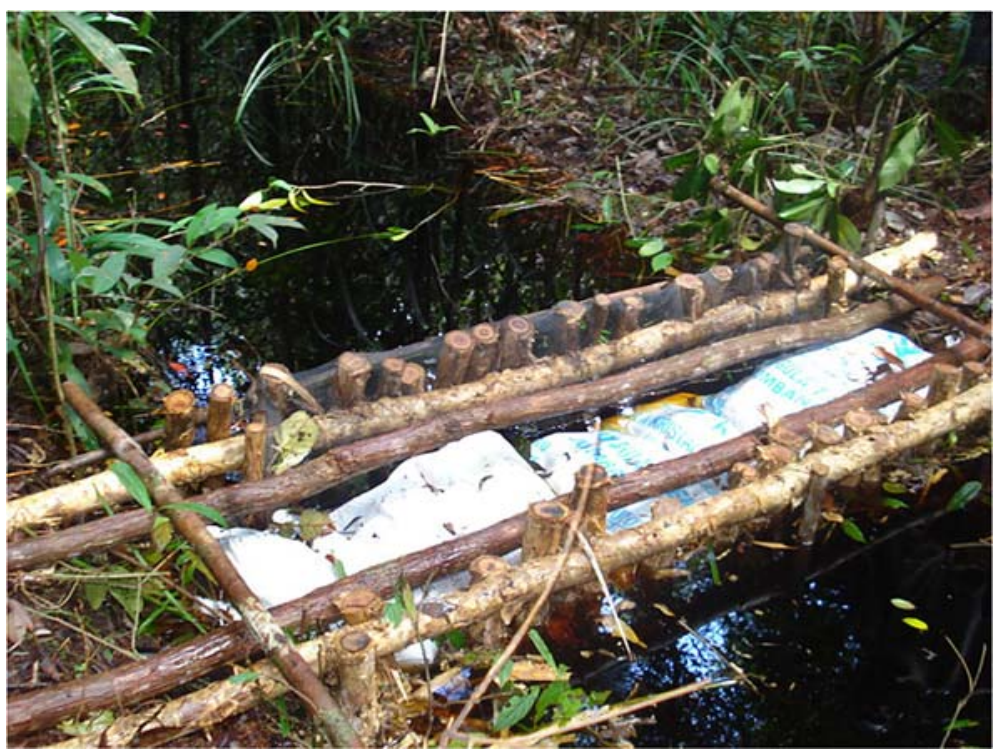

Fig. 9 Simple dam in the Bangah catchment made of locally available material (3 $\mathrm{m}$ long, $1 \mathrm{~m}$ wide and $2.5 \mathrm{~m}$ deep)

the water retention capacity of the blocked areas thereby creating favourable wet conditions for vegetation re-growth and eventually peatland restoration.

\subsection{Mitigation of carbon dioxide emissions}

Rewetting of drained tropical peatlands will potentially lead to large mitigations of carbon dioxide emissions (Couwenberg et al. 2009). Quantifying the rise in groundwater levels of hydrological restoration projects in peatlands together with an estimation of the mitigation in $\mathrm{CO}_{2}$ emissions caused by this rise, is important information to make greenhouse gas emission mitigations tradable under the voluntary carbon market or REDD (Reducing Emissions from Deforestation and Degradation) mechanism. Continuous, long-term groundwater level measurements in tropical peat swamp forests are rare. The only available 12 year average groundwater level recorded at the relatively intact test site is $-16 \mathrm{~cm}$, whereas this level in an adjacent, drainage affected, selectively logged forest is $-47 \mathrm{~cm}$ for the years 2004 and 2005 with normal precipitation (Jauhiainen et al. 2008). Preliminary groundwater level measurements in the drainage affected Bangah catchment indicate an average level of $-49 \mathrm{~cm}$. Consequently, an average annual groundwater level of $-50 \mathrm{~cm}$ was assumed to be a baseline level for the project area before hydrological restoration started. After construction of all dams, hydrological modelling indicates a rise of annual average groundwater levels of $20 \mathrm{~cm}$. With a reported emission mitigation of approximately 0.8-0.9 $\mathrm{t} \mathrm{CO}_{2} \mathrm{ha}^{-1} \mathrm{a}^{-1}$ per centimetre groundwater level rise (Couwenberg et al. 2009; Hooijer et al. 2006), rewetting of the $590 \mathrm{~km}^{2}$ area of the combined Bakung and Bangah catchments results in an estimated mitigated emission of 1.4-1.6 Million tons $\mathrm{CO}_{2}$ annually. This estimated emission mitigation will not be achieved in the first year after all dams have been constructed because only with time sedimentation of organic and mineral material upstream of the dams makes them fully effective. Higher emissions are expected during El Niño years, such as in 1997, 2002, 2006 and 2009 due to very low groundwater 
Fig. 10 Hydrological modelling applied to the Bangah catchment for very dry conditions on 25 November 1997. a Groundwater level rise in the whole area after construction of 114 small dams $\mathbf{b}$ Rise of the surface water level $(s w l)$ in a single canal after dam construction
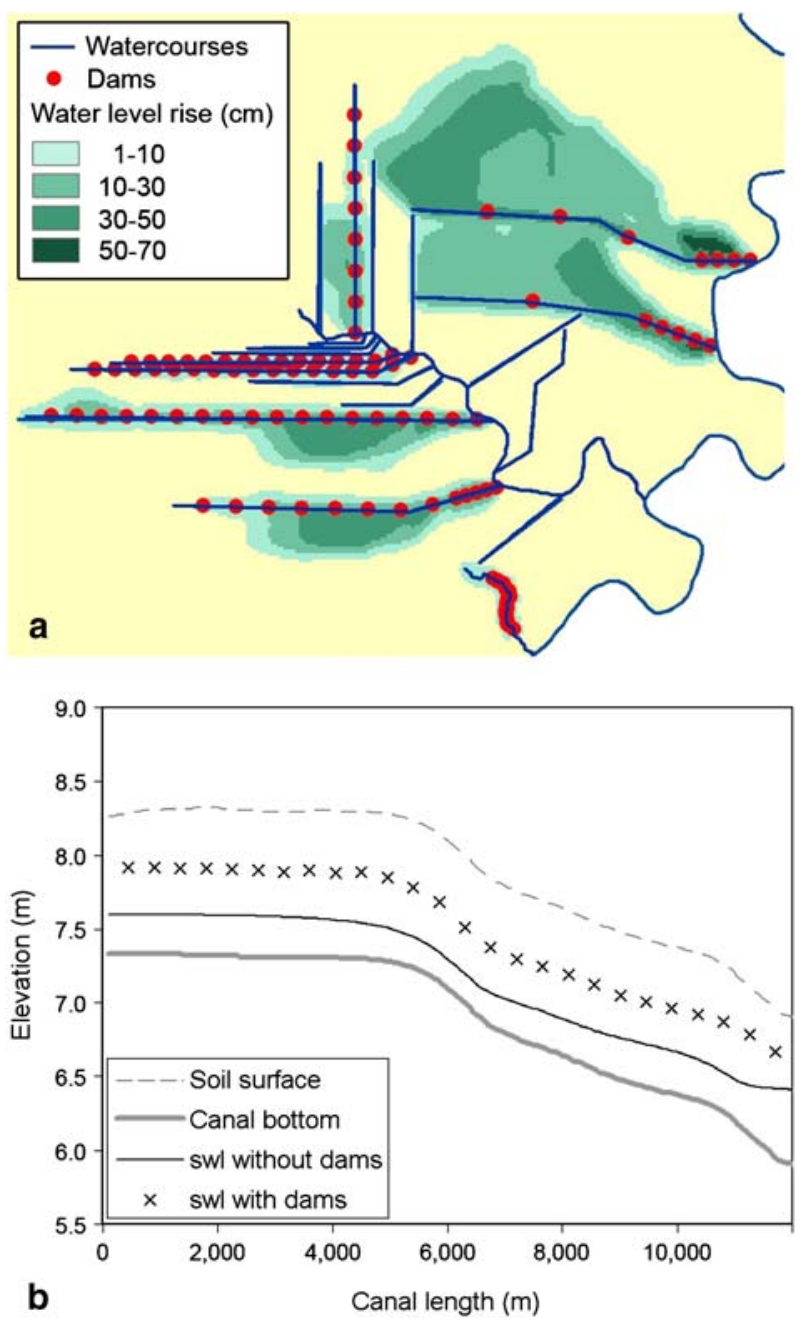

levels in addition to drainage. In the project area, long-term measurements of groundwater levels (before and after dam construction) as well as subsidence and gas flux emissions are needed to confirm these preliminary results. In this study, conservative estimates were used of both the reduced $\mathrm{CO}_{2}$ emission rate per centimetre groundwater level rise (Couwenberg et al. 2009; Hooijer et al. 2006) as well as of the magnitude of the groundwater level rise itself. Results are reported as a class to reflect the uncertainty in the calculations. Other greenhouse gases such as methane $\left(\mathrm{CH}_{4}\right)$ and nitrous oxide $\left(\mathrm{N}_{2} \mathrm{O}\right)$ are not taken into account because they are relatively unimportant in tropical peatlands (Furukawa et al. 2005; Strack 2008).

\section{Discussion}

Canals constructed for drainage and illegal logging have destroyed the hydrological integrity of many tropical peatland ecosystems (e.g. Giesen 2004; Wösten et al. 2006; Hoekman 2007; CKPP 2008). The only way to prevent soil subsidence, peat decomposition, peat fires and 
associated carbon dioxide emissions is the restoration of the hydrological integrity by raising groundwater levels and thus rewetting the peat to its original situation. Many studies have shown that groundwater levels control greenhouse gas emissions from tropical peatlands (e.g. Furukawa et al. 2005; Hooijer et al. 2006; Hirano et al. 2008; Jauhiainen et al. 2008; Couwenberg et al. 2009). However, very few practical hydrological restoration measures of degraded tropical peatlands have been reported (Jauhiainen et al. 2008; Page et al. 2008). The aim of this study was to develop a detailed plan to rewet a $590 \mathrm{~km}^{2}$ large area of highly inaccessible peat swamp forest drained by a dense network of small canals that are used by illegal loggers. The case as such is typical for many tropical peatlands in Indonesia and the proposed methodology is transferable to other drained tropical peatlands thereby increasing the knowledge base for future hydrological restoration activities. A detailed 3D peat dome model generated using remote sensing data, together with identified dam construction sites, provided input for hydrological modelling to quantify the effects of dams on raising groundwater levels. To verify the calculated groundwater levels a monitoring programme is under construction aiming at measurement of these levels in wells installed at a dam along two transects left and right, and perpendicular to the canal at 5, 25, 50, 150 and $300 \mathrm{~m}$ distances from the canal. Also water discharges will be measured in both blocked and unblocked canals. In this study wider canals were clearly visible in high resolution satellite imagery, while hardly visible, smaller canals were determined as follows: 1) canals do not run parallel to the river or cross each other because they are constructed to facilitate extraction of timber logs from the forest, 2) while in reality the course of the canals might be not completely straight, small meanders do not have any impact on the number of dams required for rewetting. Dams need to be adapted to the characteristic high hydraulic conductivity (Wösten and Ritzema 2001) and low load bearing capacity (Salmah 1992) of tropical peat. Reduced water flow in the canals allows sedimentation of organic and mineral material upstream of the dam which in turn facilitates the re-growing of vegetation. Eventually, original peat forming vegetation will fill in the canal thereby restoring the resistance to water flow in the peat swamp forest to its original value of approximately $30 \mathrm{~m} /$ day. To keep subsidence of the area surrounding the dam low, dam construction should not be too heavy. Materials like gelam timber poles and peat are suitable for dam construction and they are locally available. Blocking of a canal can be regarded successful if the blocked canal sections continue to hold water during the dry season. Since some drainage canals are used for navigation and transportation by local people, ownership of each canal should be considered and consensus should be reached before dam construction starts. Failure to do so can result in damage to the dam structures as has happened frequently in the past. After construction, monitoring and maintenance of the dams is very important, especially in the first years (CKPP 2008). Previous work in the Bangah catchment demonstrated that a field team can build 30 dams in 7 days, i.e. 53 days are required to construct all 225 dams required for the Bakung and Bangah catchments together. Labour costs for one dam (transport and material costs excluded) are approximately 150,000 IDR which is equivalent to about 10 Euro. An annual emission mitigation of $1.5 \mathrm{Mt} \mathrm{CO}_{2}$ from restored tropical peatlands is a significant amount corresponding to $6 \%$ of the carbon dioxide emissions by civil aviation in the European Union in 2006 (UNFCCC 2009), and therefore of interest for carbon crediting on the voluntary carbon market. This mitigation can be achieved with relatively small efforts and at low costs by focusing on construction and maintenance of simple dams made of locally available material. In case oxidation by drainage is limited to the top $50 \mathrm{~cm}$ of an active peat layer the total carbon at stake is 2.1 times higher than that of the aboveground biomass ${ }^{2}$. This total amount of carbon at

${ }^{2}$ A carbon content of $140.5 \mathrm{t} / \mathrm{ha}$ for peat swamp forest (Uryu et al. 2008) and of $58 \mathrm{~kg} / \mathrm{m}^{3}$ for peat soils (Neuzil 1997; Shimada et al. 2001; Supardi et al. 1993) is assumed. 
stake increases to 22 times the aboveground biomass if no hydrological restoration measures were implemented and continuous oxidation of the whole $5.4 \mathrm{~m}$ thick peat layer was allowed to take place. Increased awareness of the large amounts of carbon at risk due to tropical peatland drainage and fires promotes interest in alternative funding mechanisms such as REDD and carbon credits to safeguard these carbon stocks. Canal blocking in tropical peatlands is not only a technical but also a social challenge. Illegal logging was, besides gold mining, a main source of income for people in Central Kalimantan. Now that funding through REDD and carbon credits becomes a realistic alternative it should also be used to improve livelihoods of local people. Restoration can only be successful if local communities are actively involved in planning and implementation of restoration measures as demonstrated in this study by WWF.

Acknowledgments The authors would like to thank Guenola Kahlert, WWF Germany, for financial support. Special thanks to the WWF Indonesian field team for collecting canal data and to Prof. Hidenori Takahashi, University of Hokkaido, for the long-term measurements of rainfall and groundwater level at the test site. We gratefully acknowledge the Global Land Cover Facility (GLCF) for providing SRTM data without expense, and the US Geological Survey (USGS) for providing Landsat ETM+ imagery.

Open Access This article is distributed under the terms of the Creative Commons Attribution Noncommercial License which permits any noncommercial use, distribution, and reproduction in any medium, provided the original author(s) and source are credited.

\section{References}

Ballhorn U, Siegert F, Mason M, Limin S (2009) Derivation of burn scar depth and carbon emissions with LIDAR in Indonesian peatlands. PNAS www.pnas.org/cgi/doi/10.1073/pnas.0906457106

Boehm H-DV, Siegert F (2004) The impact of logging on land use change in Central Kalimantan, Indonesia. Int Peat J 12:3-10

CKPP (2008) Provisional report of the Central Kalimantan Peatland Project. CKPP Consortium, Nov 2008, Palangka Raya, Indonesia, p 72. http://www.ckpp.org. Cited 20 June 2009

Cochrane MA (2003) Fire science for rainforests. Nature 421:913-919

Couwenberg J, Dommain R, Joosten H (2009) Greenhouse gas fluxes from tropical peatlands in Southeast Asia. Global Change Biol. doi:10.1111/j.365-2486.2009.02016.x

Curran LM, Trigg SN, McDonald AK, Astiani D, Hardiono YM, Siregar P, Caniago I, Kasischke I (2004) Lowland forest loss in protected areas of Indonesian Borneo. Science 303:1000-1003

FIRMS (2009) Fire Information for Resource Management System. University of Maryland. http://maps. geog.umd.edu/firms/

Furukawa Y, Inubushi K, Ali M, Itang AM, Tsuruta H (2005) Effect of changing groundwater levels caused by land-use changes on greenhouse gas fluxes from tropical peat lands. Nutr Cycl Agroecosyst 71:81-91

Giesen W (2004) Causes of peat swamp forest degradation in Berbak NP, Indonesia, and recommendations for restoration. Water for Food and Ecosystems Programme, Arcadis. http:/www.waterfoodecosystems.nl

Hansen MC, Stehman, SV, Potapov PV, Arunarwati B, Stolle F, Pittmann K (2009) Quantifying changes in rates of forest clearing in Indonesia from 1990 to 2005 using remotely sensed data sets. Environ Res Lett 4:034001(12pp)

Hirano T, Jauhiainen J, Inoue T, Hidenori T (2008) Controls on the carbon balance of tropical peatlands. Ecosystems. doi:10.1007/s10021-008-9209-1

Hoekman DH (2007) Satellite radar observation of tropical peat swamp forest as a tool for hydrological modelling and environmental protection. Aquatic Conserv: Mar Freshw Ecosyst 17:265-275

Hooijer A, Silvius M, Wösten H, Page SE (2006) PEAT-CO2, assessment of CO2 emissions from drained peatlands in SE Asia. Delft Hydraulics report Q3943

Jaenicke J, Rieley JO, Mott C, Kimman P, Siegert F (2008) Determination of the amount of carbon stored in Indonesian peatlands. Geoderma 147:151-158

Jauhiainen J, Jaya A, Inoue T, Heikkinen PJ, Martikainen P, Vasander H (2004) Carbon balance in managed tropical peat in Central Kalimantan. In: Päivänen J (ed) Proceedings of the 12th International Peat Congress. International Peat Society, Tampere, pp 653-659 
Jauhiainen J, Limin SH, Silvennoinen H, Vasander H (2008) Carbon dioxide and methane fluxes in drained tropical peat before and after hydrological restoration. Ecology 89(12):3503-3514

Langner A, Miettinen J, Siegert F (2007) Land cover change 2002-2005 and the role of fire derived from MODIS imagery. Global Change Biol 13:1-12

Melling L, Hatano R, Goh KJ (2005) Soil CO2 flux from three ecosystems in tropical peatland of Sarawak, Malaysia. Tellus 57B:1-11

Neuzil SG (1997) Onset and rate of peat and carbon accumulation in four domed ombrogenous peat deposits, Indonesia. In: Rieley JO, Page SE (eds) Biodiversity and sustainability of tropical peatlands. Samara, Cardigan, pp 55-72

Ong BY, Yogeswaran M (1992) Peatland as a resource for water supply in Sarawak. In: Aminuddin BY, Tan SL, Aziz B, Samy J, Salmah Z, Siti Petimah, Choo ST (eds) Proceedings of the International Symposium on Tropical Peatland, Kuching, Sarawak, May 1991. Ministry of Agriculture, MARDI, pp 255-268

Page SE, Banks C (2007) Tropical peatlands: distribution, extent and carbon storage-uncertainties and knowledge gaps. Peatl Int 2:26-27

Page SE, Rieley JO, Shotyk W, Weiss D (1999) Interdependence of peat and vegetation in a tropical peat swamp forest. Phil Trans R Soc Lond B 354:1885-1897

Page SE, Siegert F, Rieley JO, Boehm H-DV, Jaya A, Limin S (2002) The amount of carbon released from peat and forest fires in Indonesia during 1997. Nature 420:61-65

Page SE, Wüst RA, Weiss D, Rieley JO, Shotyk W, Limin SH (2004) A record of Late Pleistocene and Holocene carbon accumulation and climate change from an equatorial peat bog (Kalimantan, Indonesia): implications for past, present and future carbon dynamics. J Quaternary Sci 19:625-635

Page SE, Hoscilo A, Wösten JHM, Jauhiainen J, Silvius M, Rieley JO, Ritzema H, Tansey K, Graham L, Vasander H, Limin S (2008) Restoration ecology of lowland tropical peatlands in Southeast Asia: current knowledge and future research directions. Ecosystems. doi:10.1007/s10021-008-9216-2

Querner EP, Povilaitis A (2009) Hydrological effects of water management measures in the Dovine River basin, Lithuania. Hydrol Sci 54:363-374

Querner EP, Jansen PC, Kwakernaak C (2008) Effects of water level strategies in Dutch peatlands: a scenario study for the polder Zegveld. In: Farrell C, Feehan J (eds) Proceedings of the 13th International Peat Congress. International Peat Society, Tullamore, pp 620-623

Rieley JO, Page SE (eds) (2005) Wise use of tropical peatlands: focus on Southeast Asia. Alterra, Netherlands. www.restorpeat.alterra.wur.nl

Salmah Z (1992) Water management in deep peat soils in Malaysia. Dissertation, Silsoe College, Cranfield Institute of Technology, UK

Shimada S, Takahashi H, Haraguchi A, Kaneko M (2001) The carbon content characteristics of tropical peats in Central Kalimantan, Indonesia: estimating their spatial variability. Biochemistry 53:249-267

Siegert F, Ruecker G, Hinrichs A, Hoffmann AA (2001) Increased damage from fires in logged forests during droughts caused by El Niño. Nature 414:437-440

Sorensen KW (1993) Indonesian peat swamp forests and their role as carbon sink. Chemosphere 27:10651082

Strack M (ed) (2008) Peatlands and climate change. International Peat Society, Jyväskylä

Supardi, Subekty AD, Neuzil SG (1993) General geology and peat resources of the Siak Kanan and Bengkalis Island peat deposits, Sumatra, Indonesia. In: Cobb JC, Cecil CB (eds) Modern and acient coal-forming environments, Boulder, Colorado, Geological Society of America Special Paper 286

Suryadiputra INN, Dohong A, Waspodo RSB, Muslihat L, Lubis IR, Hasudungan F, Wibisono ITC (2005) A guide to blocking of canals and ditches in conjunction with the community. Wetlands InternationalIndonesia Programme, Bogor

Takahashi H, Yonetani Y (1997) Studies on microclimate and hydrology of peat swamp forest in Central Kalimantan, Indonesia. In: Rieley JO, Page SE (eds) Biodiversity and sustainability of tropical peatlands. Samara, Cardigan, pp 179-187

Takahashi H, Usup A, Hayasaka H, Limin SH (2003) Estimation of ground water levels in a peat swamp forest as an index of peat/forest fire. Proceedings of the International Symposium on Land Management and Biodiversity in Southeast Asia, Bali, Indonesia, 17-20 September 2002

UNFCCC (2009) GHG data. http://unfccc.int/ghg_data/ghg_data_unfccc/items/4146.php. Cited 25 Aug 2009

Uryu Y, Mott C, Foead N, Yulianto K, Budiman A, Setiabudi, Takakai F, Nursamsu, Sunarto, Purastuti E, Fadhli N, Hutajulu CMB, Jaenicke J, Hatano R, Siegert F, Stüwe M (2008) Deforestation, forest degradation, biodiversity loss and $\mathrm{CO}_{2}$ emissions in Riau, Sumatra, Indonesia. WWF Indonesia Technical Report, Jakarta, Indonesia

Usup A, Hashimoto Y, Takahashi H, Hayasaka H (2004) Combustion and thermal characteristics of peat fire in tropical peatland in Central Kalimantan, Indonesia. Tropics 14:1-19 
Van der Werf GR, Randerson JT, Giglio L, Gobron N, Dolman AJ (2008) Climate controls on the variability of fires in the tropics and subtropics Global Biogeochem Cycles 22, GB3028, doi:10.1029/ 2007GB003122

Whitten AJ, Damanik SJ, Anwar J, Hisam N (1987) The ecology of Sumatra. Gadjah Mada University Press, Yogyakarta

Wösten JHM, Ritzema HP (2001) Land and water management options for peatland development in Sarawak, Malaysia. Int Peat J 11:59-66

Wösten JHM, Ismail AB, Van Wijk ALM (1997) Peat subsidence and its practical implications: a case study in Malaysia. Geoderma 78:25-36

Wösten JHM, Hooijer A, Siderius C, Satriadi Rais D, Idris A, Rieley JO (2006) Tropical peatland water management modelling of the Air Hitam Laut catchment in Indonesia. Int J River Basin Manag 4:233244

Wösten JHM, Clymans E, Page SE, Rieley JO, Limin SH (2008) Peat-water interrelationships in a tropical peatland ecosystem in Southeast Asia. Catena 73:212-224 